\title{
The Empirical Analysis of Technical Efficiency on Large Scale Grain Production in North West Ethiopia: A Stochastic Frontier Approach
}

Woretaw Workneh ( $\nabla$ woret2003@gmail.com )

\section{Research}

Keywords: large scale major grain crop, Efficiency, Stochastic frontier, Production, Ethiopia

Posted Date: September 15th, 2021

DOI: https://doi.org/10.21203/rs.3.rs-871732/v1

License: (a) (i) This work is licensed under a Creative Commons Attribution 4.0 International License.

Read Full License 


\title{
Journal of Economic Structures
}

\section{The Empirical Analysis of Technical Efficiency on Large Scale Grain Production in Northwest Ethiopia: A Stochastic Frontier Approach}

\author{
Woretaw Motbaynor Workneh, \\ Department of Economics, Bahir Dar University \\ Email; woret2003@gmail.com
}

\begin{abstract}
This study is intended to scrutinize the technical efficiency of large-scale grain crop producers in Northwest Ethiopia. Moreover, the study endeavored to determine socioeconomic characteristics, and farm management practices which influence the technical inefficiency in large scale grain production. Multiple stages random sampling technique was used to select 200 producers. The empirical results revealed that capital, labor, land, and seed input affect the output positively. The responsiveness of yield shows that a one-percent increase in utilization of capital, labor and land inputs will increase the grain production by $0.18 \%, 0.23 \%$ and $0.56 \%$ respectively, while the agrochemical input influences the output negatively. Evidence from the technical inefficiency model shows that gender and levels of education variables increase technical efficiency. Age, occupation, district, and subsidies variables increase technical inefficiency. Producers' technical efficiencies range from 23 to $100 \%$ and the mean technical efficiency is $71.7 \%$. More effort should be made for adult and continuing education. Female producers should be given an opportunity in the management place in the large-scale grain farming segment. In addition, the government is compelled to give strategies about proper input appliance and set up the pilot research institution in the study area.
\end{abstract}

\section{Key words: large scale major grain crop, Efficiency, Stochastic frontier, Production, Ethiopia}

\section{Introduction}

Reviewing the basis of augmentation and production competency of the agricultural sector is an important stride in quantifying the developmental roles that agriculture plays in Africa. The Ethiopian economy is tremendously reliant on agriculture as the sector contributes about $47 \%$ of the prime shares to the national GDP; $85 \%$, employment generation, $90 \%$ of exports and providing about $70 \%$ of raw material for the industries in the country (AfDB 2016; FDRE 2016; UNDP 2015). Moreover, agriculture comprised $80 \%$ of the livelihood of the country's total population (MoFEC 2015). The performance of grain crops has been a major source of overall progress in agriculture and related activities (MoFED, 2010; NPC, 2016).

Ethiopia is the prime grain crop producer in Africa. According to CSA (2019) survey reports, can be obtained 315,602,059 quintals of total grain yield by using a total of 12,727,191 hectares of cultivated land. Out of the total grain crop area, $81.2 \%$ (10,358,890 hectares), $12.7 \%(1,620,497$ hectares) and $5.9 \%(747,804$ hectares $)$ of the grain crop area and $88 \%(277,638,381$ quintals $), 9.54 \%$ 
$(30,113,481$ quntials $)$ and $2.5 \%$ (7,850,197 quintals) of the grain production was drawn from cereals, pulses, and oil seeds, respectively (CSA 2019).

In Ethiopia, sesame is the leading oilseed crop in terms of production value and the second grain crops that earn foreign exchange. It accounts $2.4 \%$ (299,899 hectares) of the entire grain area and $0.65 \%(2,016,647$ quintals) of total grain production (CSA 2019). It is largely produced by large scale sesame producers who cultivate about 281,346 hectares and produced more than 224,326 tones (FDRE, 2015). Even if, sesame is produced in all the regions of the country with differing measure, the primary share of production, which is about $75 \%$ of the national product produced, is from western Amhara (Metema, West Armachiho and Qura) about 44\% and from Western Tigray (Humera) regions about $31 \%$ of the country (CSA 2019; MoTI 2019).

Sesame production has shown a greater amplify in area and production over the past years. However, its countrywide average productivity is dwindling from 8.5 quintals/ha in the year 2004/5 to 7.4 quintals/ha in 2013/14 (CSA 2014) and to 6.9 quintals/ha in 2015/16 (CSA 2016). In addition, its productivity in the year $2018 / 19$ is 6.1 quintals/ha, which is lower than the estimated FAO prospective, about 16 quintals/ha. This indicates that the present productivity of sesame in Ethiopia in general and in the study, district is far below the expected national average (CSA 2019; FAO 2015; Wijnands et al. 2007).

Ethiopia is the principal grain crop (sorghum) producer in eastern and southern Africa next to Sudan. In Ethiopia, Sorghum ranks third next to maize and teff in the total grain production. Sorghum accounts $14.4 \%(1,829,663$ hectares $)$ of the total grain area and covers about $16 \%$ $(50,243,681$ quintals) of the grain production (CSA 2019). In Ethiopia about $75 \%$ of the total national sorghum product is produced in the northwest part of the country, which is about $39.5 \%$ from Oromia and $34.5 \%$ from Amhara reigns of the country. However, sorghum productivity shows an increment in the recent years, the countrywide average sorghum productivity is 2.4 tons/ha, which is far below the worldwide average of 3.2 tons'/ha (CSA 2017; CSA 2019). And also, its productivity in the study district is lower than the countrywide.

Moreover, the total sorghum production in the year 2018/19, 50,243,681quintals is lower than its total production in the year 2016/17, 51,692,525 quintals. Sorghum productivity trend shows that sorghum yield and production statistics during 2006 to 2012 and 2016 to 2019 are lower than the regime average (CSA 2019; FDRE 2016).

Among a few countries in Africa, Ethiopia is one of the enormous grain crops (cotton) producers and in terms of its production value the crop is the most important in the country. Ethiopia ranks as the world's fourth largest producer (EIA 2013). In Ethiopia, there is a projected 2,697,640 hectares of pertinent land convenient for large scale cotton producers (CSA 2019). Even if cotton has grown in many of the regions in the country, there are plenty potential areas in the western Amhara region (Metema, West Armachiho and Qura), 25\% (678,710 hectares), and in SNNP (Awash valley and 
Omorate) region, 22\% (600,900 hectares) (EIA 2013). However, from the total accessible areas of cotton production, merely 3\% (111,886 hectares) of land is being utilized (MoARD 2010).

There was an average of 46,000 metric tons of cotton production in the years between 2010 and 2020 . The country produces a minimum of 28,000 metric tons and a maximum of 62,000 metric tons in the year 2013/14 and 2012/13, respectively (FAOSTAT 2016; USDA 2018). This indicates that there is a dwindling phase starting from the year 2012. Due to inadequate use of agrochemical and fertilizer inputs the existing cotton production is below its prospective (EIA 2013). Therefore, the total grain production tendency in Ethiopia shows that there was an increase in total grain production and area cultivated. However, this increment in output could not be accredited to improvement in productivity (CSA 2015; FDRE 2015).

According to some of the existing studies, in Ethiopia, the agricultural sector is elucidated by inadequacies and destitute productivity and working below its prospective production capacity (WFP 2010; Wijnands et al. 2007). The existing production system suffers from customary farming practices, underutilized economic resource, use of unimproved seed, lack of fertilizer use (Abu and Quintin 2013; Gelalcha 2009; Kifle 2017). Furthermore, it has also been perceived that the economy's technical efficiency and technological progress are at a low-level (NPC 2016).

In Ethiopia, most of the grain crop producers are making different levels of outputs with the same resource. Major factors to the existence of inefficiency in grain productivity are related to shortage of improved/modern agricultural inputs and inadequate agricultural extension system (FAO and WFP 2012; Kifle 2017; NPC 2016). This indicates that, with the existing factors of production, grain crop producers are technically inefficient because they are producing below their prospective output (Wijnands et al. 2007). In addition, the yield of grain crop in Ethiopia is almost low as compared to other countries that have a practice of using mechanized agriculture.

Now a day, in Ethiopia agriculture and rural transformation targets of the GTP II plan aims to boost agricultural production by solving the problems of input supply and technology adoption. In the GTP II plan, the government states that productivity enhancement in the agricultural sector is only potential through proper management and dissemination of available technologies and tackling the challenges which have an influence on the achievement of producers' efficiency prospective (Alemayehu 2010; UNDP 2015; World Bank 2017).

These reviews emphasize the extent of knowing the efficiency levels of large scale ${ }^{1}$ major grain production in Ethiopia, that have vigorous impacts; On providing job opportunity for citizens, raw materials for industries, technological capacity for higher yields and returns, and improve the proponent living standard (ensuring food security). In addition, the sector will meet ARDS through bringing hard currency of the nation by producing market oriented agricultural products and will

\footnotetext{
${ }^{1}$ During this study, the name "large scale" does mean to be considered as large-scale grain production/farming or large-scale agricultural investment in the study area.
} 
transfer technologies for small-scale producers (FAO 2018; MoFED 2010; NPC 2016). Therefore, for Ethiopia as an agriculturally reliant country with a food dearth gap, rising large scale agricultural production and enhancing large scale grain production efficiency is not a matter of option, but is instead a Duty.

Over the years, various methods of estimating production frontiers have been developed and come up with consistent efficiency measures. These frontier methods vary from econometric to noneconometric methods (Aligner et al. 1977). Stochastic frontier models have become a well-liked auxiliary meadow in econometric. Kumbhakar et al. (2000) offer an improved preamble about frontier production models to measure technical efficiency. Technical efficiency proclaims as the ratio of observed output to and the maximum output. Or, alternatively, producers are assumed to attempt on their production function, maximizing outputs offered from the inputs they use.

The stochastic frontier functions both emerge a composite error term involving technical inefficiency of the production process and the probabilistic, random effects leading to productive inefficiency. This aids the scientist to quantify both the technical efficiency sources and impact of measurement errors or factors that are not directly associated to the production process itself.

Among the empirical results that have employed the econometric method, the authors Abate et al. (2006); Addai and Owusu (2014); Alemu et al. (2009); Ahmed and Melesse (2018); Amodu et al. (2011); Chakwera (2015); Ermiyas et al. (2015); Getachew and Bamlak (2014); Gemechu (2014); Hassen (2016); Haile et al. (2018); Hailemaraim (2015); Ibrahim et al. (2014); Kibara (2005); Solomon (2014); Tchale and Sauer (2007) have found that the socioeconomic factors: education, access to credit, age, gender, access to extension service, market access, land holding size, access to improved technologies, and non-physical factors have a noteworthy upshot on technical efficiency.

Most of these productivity and technical efficiency measurement studies, testimony confirming that in the agricultural sector still there are low levels of production efficiency know-how in the developing countries in general and in Ethiopia in particular.

Ethiopian economy, largely dependence on rain-fed and incredibly habitual farming practices; the country has scanty modern resources and less opportunity for adopting better modern technologies. Thus, measurement of efficiency in large scale agricultural production, gives useful and powerful information for making relevant decision on the use of the scanty resources and inventing proper agricultural strategies

In Ethiopia, some empirical works have been done to scrutinize technical efficiency of smallholder growers using different methodologies. However, the findings of these studies might not be associated to the case of large-scale grain production due to discrepancies with the sympathy of the producers, factors of production and the means of production, the yield produced and unlike agro-ecological district. Furthermore, there is no a large amount empirical work on the technical efficiency of large scale grain production, and the reliance of technical efficiency on capital inputs, subsidy access, energy inputs and agro-ecological factors in Ethiopia, primarily in the study area. 
According to EPLAUA of Amhara region (2018) reports that $74 \%$ of the total grain crop area had been leased out to more than two thousands of large-scale sesame, cotton and sorghum major grain crop producers in the study area. The large farming land offered for producing these major grain crops in the study area, the potentials for intensifying production volume is great (Alemayehu 2010). So, it is very important to conduct a study on measuring the efficiency of large-scale grain crop producers in Ethiopia. Therefore, this study examines whether large scale sesame, cotton and sorghum grain production are technically efficient and identifies the determining factors in Metema, West Armachiho and Qura Districts, Northwest of Ethiopia, using a stochastic frontier production function model.

Hypothesis: in this study the $1^{\text {st }}$ null hypothesis states that producers are technically efficient, and no production loss is attached to technical inefficiency of the grain crop producers $\left(H_{0}:=u=0\right)$. It denotes that the $i^{\text {th }}$ producer is operating on their efficient production frontier and the effects of statistical noise and technical inefficiency is zero. The $2^{\text {nd }}$ null hypothesis avows that variable included under the inefficiency effects analysis are not greatly influence the producers' technical inefficiency in the study area $\left(H_{0}: \lambda=\delta_{0}=\delta_{2} \ldots \delta_{p}=0\right)$.

\section{Materials and Methods}

\subsection{Description of the Study Area}

The study is conducted in Metema, West Armachiho and Qura Districts, Western Amhara National, Regional State (ANRS), Northwest of Ethiopia. In the district, the primary source of livelihoods is agriculture (i.e., Grain production). Naturally, the study area is well-endowed with large fertile land which makes it suitable for large scale grain production. The sector employs about $90 \%$ of the working force, and it comprises the largest tracts of grain production. Sesame, sorghum, and cotton are the major grain crop grown in the districts. The total cultivated land is $549,801.83$ hectares. Out of this cultivated land, 322,794.8 hectares of land are used for grain production. The land covered by the three major grain crop (sesames, cotton, and sorghum) is 234,443 hectares, which is about $74 \%$ of the total grain crop area in the district (EPLAUA 2017/18). 


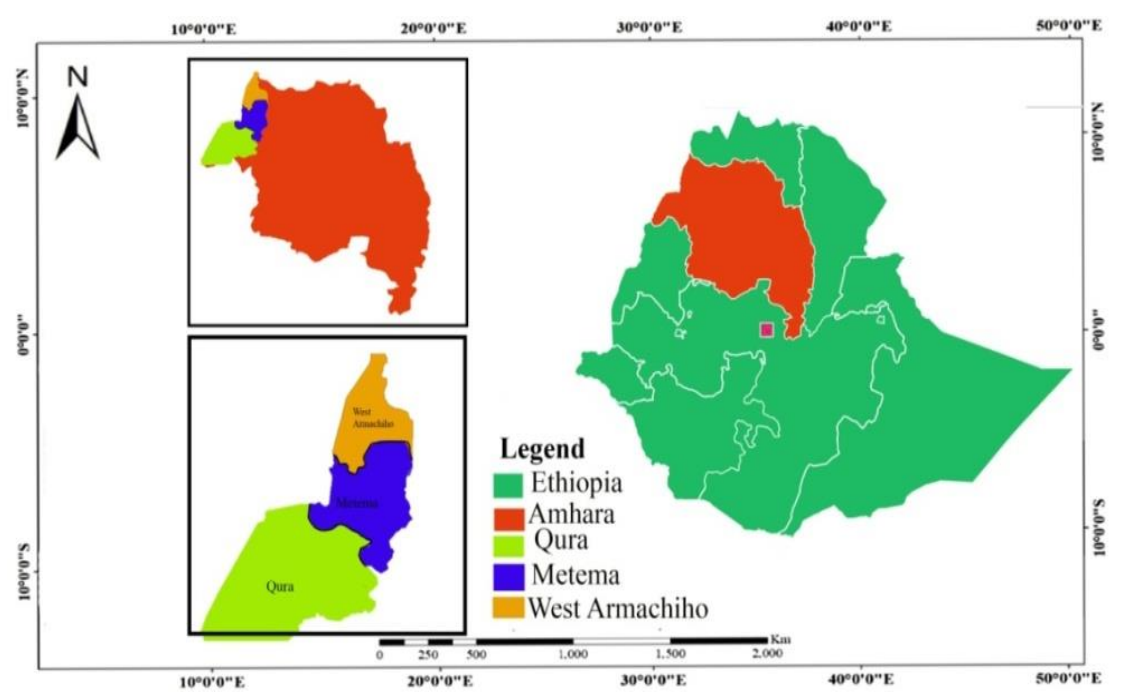

Figure 1: Map of the study area. Source; Author's compilation

\subsection{Sampling Technique and Sample Size Determination}

In this study a multi-stage sampling technique is used to select the sample producers. In the first step, three districts (Metema, West Armachiho and Qura) are selected purposely due to high land acquisition and potentials of large-scale sesame, cotton, and sorghum major grain production. In the next step, the study employed both stratified and systematic random sampling techniques for selection of the sample of the household head. This proportionally represents the population size of the largescale sesame, cotton, and sorghum producers. Next to, 92 large scale producers from West Armachiho district, 78 from Metema district and 32 from Qura district were randomly sampled, giving upswing a total of two hundred (200) large scale grain crop producers, who are individually owned a minimum of 10 hectare $^{2}$ land was used for the study.

\subsection{Methods of Data Collection}

This study used both quantitative and qualitative data. And both primary and secondary data sources were used. Primary data were collected through a face- to-face interview via structured survey questionnaires, which contain both open and closed-ended, detailed questions for households and respecting government offices/employees. Six enumerators were assigned to oversee the questionnaire to the respondents. Ultimately, two hundred questionnaires were used for the final analysis. Secondary data were emanated from large scale producers' documents, checklists of facts, past reports and studies conducted by institutions and scholars. The information collected includes capital, labor, land, agrochemical, and energy inputs, output and input prices, and farmers' socioeconomic characteristics such as age, occupation, level of education, gender, extension service, subsidy, and district etc.

\footnotetext{
${ }^{2}$ During this study, the margin land size to be considered as "large-scale" (large scale grain crop producers or large-scale agricultural investors or farmers are taken as land equal to or greater than 10ha.
} 


\subsection{Specification of the Model and Methods of Data Analysis}

The frontier model originates by Aligner et al. (1977) and extended by Kumbhakar et al. (2000) is applied in this study. The grain production with the stochastic additive error term of the farm is shown below

$$
Y_{i}=f\left(X_{i j} \beta\right) \exp \left(E_{i}\right)
$$

where $\mathrm{i}=1,2,3, \ldots, \mathrm{N}$ farmers. $\mathrm{Y}_{\mathrm{i}}$ is the output level of, the $i^{\text {th }}$ sample producer, $f\left(X_{i j} \beta\right)$ is the production frontier, a suitable function for Cobb-Douglas or translog production functions, $\mathrm{X}_{\mathrm{i}}$ is a vector of inputs associated with the $i^{\text {th }}$ farm used for grain production, and $\beta$ is the vector of production parameters. $\mathrm{E}_{\mathrm{i}}$ is the stochastic disturbance term, which comprises the symmetric part, $\mathrm{V}_{\mathrm{i}}$, accounts for factors outside the grain crop produces' control, such as weather, diseases and measurement error. $V_{i}$, assumed to be a disturbance term individualistically and identically scattered random variable $\left(0 ; \sigma V^{2}\right)$. Alternatively, the distribution of $\mathrm{U}_{i}$ is a non-negative truncated normal, $N\left(0 ; \sigma^{2}{ }_{w}\right)$ and it displays the technical inefficiency relation to the production frontier $f\left(\mathrm{X}_{\mathrm{ij}} \mathrm{B}\right)$, ranges between the values of zero and one.

By using $\left(\mathrm{E}_{\mathrm{i}}=\mathrm{U}_{\mathrm{i}}+\mathrm{V}_{\mathrm{i}}\right)$. Equation (2) can be reaffirmed as.

$$
\mathrm{Y}_{\mathrm{i}}=\mathrm{f}\left(\mathrm{X}_{\mathrm{ij}} \mathrm{B}\right) \exp \left(\mathrm{v}_{\mathrm{i}}-\mathrm{U}_{\mathrm{i}}\right)
$$

Following Kumbhakar et al. (2000), technical efficiency of the $i^{\text {th }}$ grain crop producer would be estimated as follows:

$$
\mathrm{TE}_{\mathrm{i}}=\frac{\mathrm{Y}_{\mathrm{i}}}{\mathrm{Y}_{\mathrm{i}}^{*}} \text {, }
$$

where $\mathrm{TE}_{\mathrm{i}}$ is grain production, technical efficiency score by the $i^{\text {th }}$ producer,

$\mathrm{Y}_{\mathrm{i}}=\exp \left(\mathrm{X}_{\mathrm{ij}} \beta+\mathrm{V}_{\mathrm{i}}-\mathrm{U}_{\mathrm{i}}\right)$ is the observed output for $i^{\text {th }}$ producers as specified by Eq. (1), and $\mathrm{Y}^{*}{ }_{\mathrm{i}}=\frac{\mathrm{Y}_{\mathrm{i}}}{\mathrm{TE}_{\mathrm{i}}}=\exp \left(\mathrm{X}_{\mathrm{ij}} \beta+\mathrm{V}_{\mathrm{i}}\right)$ is the highest predicted value for $i^{\text {th }}$ producers which assumes a technically efficient production? By using the equation (3) can be describe equation (4) as follows:

$$
\mathrm{TE}_{\mathrm{ij}}=\frac{\mathrm{Y}_{\mathrm{i}}}{\exp \left(\mathrm{X}_{\mathrm{ij}} \beta+\mathrm{v}_{\mathrm{i}}\right)}=\frac{\exp \left(\mathrm{X}_{\mathrm{ij}} \beta+\mathrm{v}_{\mathrm{i}}-\mathrm{U}_{\mathrm{i}}\right)}{\exp \left(\mathrm{x}_{\mathrm{ij}} \beta+\mathrm{V}_{\mathrm{i}}\right)}=\exp \left(-\mathrm{U}_{\mathrm{i}}\right),
$$

It can be simplified to $\mathrm{TE}_{\mathrm{ij}}=\exp ^{\left(-\mathrm{U}_{\mathrm{i}}\right)}$. Seeing as the real production is usually less than the frontier production $\left(Y_{i} \leq Y^{*}{ }_{i}\right)$, the possible values for technical efficiency found between 0 and 1 interval, with a technical efficiency of 1 indicating that the real production is equal to the frontier production and producers are said to be technically efficient.

The intended stochastic production function was estimated using a Cobb-Douglas formulation (Battese and Coelli 1995), where the natural logarithm of gross income or yields per hectare expressed in Ethiopian Birr is measured as a dependent variable. 
According to EIAR (2011), with respect to a cropping system in Ethiopia, mostly large-scale grain crop producers in the Western Amhara region have started practicing a blend of the grain crops from the same plot. Or they grow one crop in one plot, with later rotation of oil crops and cereals. Sometimes they heap it together with another crop of the equivalent kind from another plot after coming to a threshing point, it is nearly difficult to express in terms of $\mathrm{kg}$ or quintals/ha. Therefore, all major grain crop outputs were converted into monetary values using the price information collected the survey and developing the conversion index. The analysis was conducted at household level. Hereafter the stochastic frontier model specified at household level is articulated as:

$$
\operatorname{LnY}_{\mathrm{i}}=\beta_{0}+\Sigma \beta_{\mathrm{n}} \mathrm{X}_{\mathrm{i}}+\mathrm{E}_{\mathrm{i}}
$$

where $\operatorname{Ln}=\operatorname{Logarithm}$ to base $e, \mathrm{Y}_{\mathrm{i}}=$ The output of the major grain crop producers,

$\beta_{i}=$ The parameters to be estimated, $X_{i}=$ the input used (labor, fertilizer, seed, agrochemical, capital, energy, and land)

Table 1. Name and dimension of variables considered in the equation (6 and 8).

\begin{tabular}{|ll|}
\hline Variables & Variable name and measurement \\
\hline seed & Amount of improved seed used (kg) \\
Fert & Amount of inorganic fertilizer used (kg) \\
Cap & Amount of labor used (man hours) \\
& Amount of capital input (tractors, combines and other machineries) used (in \\
birr) & Land size, areas covered by the three grain crops (hectares) \\
Eng & Sum of energy input (fuel, grace, benzene, and others) used (in birr) \\
agrochm & Amount of agrochemical input used (in litter) \\
age & The age of household head in years that can be served as a proxy variable for \\
& farming experience \\
Distr & $\begin{array}{l}\text { District, geographical site that is used to account any site-specific factors of the } \\
\text { study areas (soil fertility, difference in environmental conditions, far from the }\end{array}$ \\
relating institutions and markets). \\
Edu & The education level of the household head measured in years of schooling \\
extcont & A number of extension contacts on farmland management in the year \\
Gend & The gender of the household head measured as dummy variables' \\
Occop & The major livelihood of the producers measured as dummy variables' \\
Subsidy & Subsidy access, payments that producers received directly or indirectly from the \\
& government and other institutions (such as credit, tax duty-free of agricultural \\
& machineries and other materials
\end{tabular}

The empirical stochastic frontier production model used is specified as: $\operatorname{Ln} Y_{1}=\beta_{0}+\beta_{1} \operatorname{Ln}($ seed $)+\beta_{2} \operatorname{Ln}($ fert $)+\beta_{3} \operatorname{Ln}($ lab $)+\beta_{4} \operatorname{Ln}($ cap $)$

$$
+\beta_{5} \operatorname{Ln} \operatorname{lan}\left(\text { siz) }+\beta_{6} \operatorname{Ln}(\mathrm{eng})+\beta_{7} \operatorname{Ln}(\text { agrochm })+V_{i}+\mathrm{U}_{\mathrm{i}} .\right.
$$

The spotlight of the above function is to give an empirical analysis of the determinants of productivity variability gaps between large scale grain crop producers in the study district. In the next analysis, we explore farmland and producer-specific features that have an impact on large scale grain crop producers' technical efficiency. The inefficiency model can be stated as: 


$$
U_{i}=\delta_{i}+\sum_{i=0}^{z} \delta Z_{i}
$$

where $\mathrm{U}_{\mathrm{i}}=$ the inefficiency model and the variable $Z_{i}$ (that is, age, gender, education level, occupation, district, extension contact and subsidy accesses) are the large-scale grain crop producers' characteristics that have a predictable effect on efficiency. Assumed that there are independently distributed inefficiency effects and $U_{i j}$ ensues at truncated normal distribution with mean $\mathrm{U}_{\mathrm{ij}}$ and variance $\mathrm{U}^{2}$ where $\delta U_{i j}$ stipulated as.

$\mathrm{U}_{\mathrm{i}}=\delta_{0}+\delta_{1}$ age $+\delta_{2}$ distr $+\delta_{3}$ edu $+\delta_{4}$ extcont $+\delta_{5}$ gend $+\delta_{6}$ occop $+\delta_{7}$ subsidy

Given the model generates variance parameters $\left(\delta^{2}{ }_{v}\right.$ and $\left.\delta^{2}{ }_{w}\right)$ be the variances of the parametric symmetric $(V)$ and a one- sided error term $(U)$ which show that.

$$
\sigma^{2}=\delta_{v}^{2}+\delta_{w}^{2}
$$

The ratio of the two standard errors as used by Kibara (2005) $\lambda=\frac{\delta_{u}}{\delta_{v}}$, as it could be visualized, the parameter $\lambda$ is an indicator of the relative variability of the two sources of variations. If $\lambda=0$, there is no inefficiency, if $\lambda>1$, the one - sided error term $U$ dominates the symmetric error term $V$. The variance ratio parameter $\gamma$, which relates the variability of $\mathrm{U}_{i}$ to the total variability $\left(\delta^{2}\right)$ can be calculated in the following way.

$Y=\frac{\delta^{2} u}{\left(\delta^{2} v+\sigma^{2} u\right)}=\frac{\lambda^{2}}{\left(1+\lambda^{2}\right)}$. Gamma $(Y)$, measures the level of inefficiency and takes a value in the interval $(0,1)$, if the worth $Y$ equals zero, the variation between the yields of producers is utterly owing to probabilistic, random effects. While, if the worth of $Y$ equals one would show that the difference is ascribed to technical inefficiency (Coelli, 1995). On the assumption that $V_{i}$ and $U_{i}$ are independent and normally distributed, the parameters $\beta, \delta^{2}{ }_{u}, \delta^{2}{ }_{v}, \delta^{n}, \gamma$ and $\lambda$ were projected using Maximum Likelihood estimation methods and the test statistics were computed automatically where the frontier production model was estimated using STATA version 14.

\section{Results and Discussion}

\subsection{Demographic and Socioeconomic Characteristics of Households}

The socioeconomic characteristics of large-scale grain crop producers are presented in able 1 . The descriptive analysis result shows that from the entire number of the respondents, $96 \%$ and $4 \%$ were male and female headed household respectively. The mean technical efficiency (81\%) of the female producers is higher than the male producers $(71 \%)$. Female producers are found to be more effective than their counterpart. The producers' age ranges between 33 and 60 years. Many of the respondents (52\%) are between the age of 41 and 50 years. The mean age is 46.5 years. This implies that most of the producers are economically active, and they can make a positive contribution to grain production. In the study area, about 59\% of sample household were literate. However, 55\% of respondents with 75 percent mean technical efficiency had a school-leaving certificate. 
The dummy variable subsidy indicates that subsidized producers are more efficient than the other ones, because the availability of the subsidy will reduce the constraint of grain production and facilitate to get agricultural inputs on time with less cost.

An upsurge in farm size is argued to enhance the mean technical efficiency of the producers. The survey result shows that producers who acquired above 200-hectare land were more profitable than those who acquired below 200-hectare land. The result is supported by the finding of Abate et al. (2006), the effect of farm size on the technical efficiency of grain production shows that large scale producers with $74 \%$ mean technical efficiency were more efficient than smallholder producers (68\%). This can be explicated by the truth that large scale producers are more advantages to acquire and utilize higher market shares and they can access resource along with economics scale and capacities associated with large farm size. Thus, the large-scale producers can improve their technical efficiency compared with the small ones

Table 1. Descriptive information for the socioeconomic variables of large-scale grain crop producers in the study area

\begin{tabular}{|llll|}
\hline Dummy variables & Response & Frequency & Percentage \\
\hline Gender $(1=$ Male, and $0=$ & Male & 192 & 96 \\
Female & Female & 8 & 4 \\
Subsidies $(1=$ Yes and $0=$ N0) & Yes & 44 & 22 \\
& No & 156 & 78 \\
Extension $(1=$ Contact and & Yes & 22 & 11 \\
0= No contact) & No & 178 & 89 \\
Occupation $(1=$ farmer and & Yes & 185 & 92.5 \\
0=others) & No & 15 & 7.5 \\
Level of education & Illiterate & 82 & 41 \\
(Illitrate=5, & School leaving certificate & 110 & 55 \\
School leaving certificate=4, & Primary school & 5 & 2.5 \\
Primary school complete $=3$, & completes & & \\
Higher education=2, & Higher education & 2 & 1 \\
Specific professional & Specific professional & 1 & 0.5 \\
training=1) & training & & \\
District & Metema & 76 & 38 \\
0= Metema & Qura & 32 & 16 \\
1= Qura & West Armachiho & 92 & 46 \\
2=West Armachiho & & & \\
Land size (ha) & $<=200$ & 119 & 59.5 \\
& 200-1000 & 74 & 37 \\
& $>1001$ & 7 & 3.5 \\
\hline Continuous variables & Unite & Mean & Std. Dev \\
\hline Age & Years & 45.7 & 6.37 \\
Land & Hectare & 238.97 & 273.78 \\
Yield & Quintal/ ha & 13.92 & 1.29 \\
Actual Yield & Quintal & 63829 & 11088 \\
\hline
\end{tabular}

Source: Field survey, (2018/19) 
In the study, 38\%, $46 \%$ and $16 \%$ of the large-scale producers are in Metema, West Armachiho and Qura district, respectively. The producers have $74 \%, 71 \%$ and $66 \%$ mean technical efficiency in Metema, West Armachiho and Qura district, respectively. Therefore, this indicates that the mean technical efficiency is higher in Metema district and lowest in the Qura district. The reasons for the efficiency variation across these areas might also be due to lack of resources, technical assistance from the responsible institutions. From the result, $92.5 \%$ of the respondents are farmers.

\subsection{The maximum likelihood estimates of the frontier production parameters for the major grain crops (in aggregate)}

Before using all the projected variables into the model estimation, an attempt tests were applied for model validity checking. Such as a multicollinearity test using Variance Inflation Factor (VIF) and heteroscedasticity test using the Breusch-Pagan test was made for all assumption of the stochastic frontier approach. Then the value of VIF and contingency of all variables entered the analysis was below 10 and 0.75 , respectively. Then the result confirms that there are no multicollinearity and heteroscedasticity problems in the model.

A test against on the presence of inefficiency effect is approved by conducting a likelihood ratio test assuming the null hypothesis of no production loss attached to technical inefficiency $\left(\mathrm{H}_{0}\right.$ : sigma $\left.\mathrm{u}=0\right)$. The calculated value of likelihood ratio test exceeds the critical value (Table 2). The result indicated that the inefficiency component of disturbance tern $\left(\mathrm{U}_{\mathrm{i})}\right.$ is drastically different from zero; most variables in the error component and technical inefficiency effects model are statistically significant. The null hypothesis of technical inefficiency effect is rejected.

Furthermore, hypothesis test made on the null hypothesis assumption $\left(\mathrm{H}_{0}: \sigma_{0}=\sigma_{1}=\sigma_{\mathrm{p}}=0\right)$ of the joint effect of the socioeconomic variables on technical inefficiency is not statistically significant. The premeditated likelihood ratio test value was greater than the critical value (table 2). This illustrates that there are statistically significant effects of the variables on technical inefficiency. Thus, the null hypothesis is not accepted, and all variables incorporated in the analysis were concurrently explaining the basis of efficiency variation between the sample producers.

\section{Table 2. Likelihood Ratio Tests}

\begin{tabular}{|lllll|}
\hline The Null hypothesis test & Calculated value & Df & P value & Decision \\
\hline$H_{0}: u=0$ & 1.10 & 1 & 0.000 & Reject Ho \\
$\left(H o: \lambda=\sigma_{0}=\sigma_{2}=\ldots \sigma_{p}=0\right)$ & 213.15 & 9 & 0.000 & Reject Ho \\
\hline
\end{tabular}

The result in table 3 shows that the variance of the farm effect is a significant proportion of the total variability of the value of major grain production (in aggregate). In the translog model, $\gamma$ is estimated at 0.96 , this can be interpreted as $96 \%$ of the total variation in the total of the major grain crop is owing to technical inefficiency. Lambda $(\lambda)$ is greater than one. It indicates that the one-sided error term $\mathrm{u}$ dominates the symmetric error $\mathrm{v}$, so variation in actual grain crop yield comes from differences 
in large scale producers practice than random variability. Such a result, according to Musa (2014); Ahmed and Melesse (2018); Kifle (2017), indicate a good fit for the model.

The coefficients of land, capital, labor, and seed inputs are $0.746,0.085,0.089$ and 0.005 , respectively shows that the coefficients are positive and statistically significant. This implies that as the amount of land size, capital, labor and seed input increased by $1 \%$, the amount of aggregated total grain produced also increased by $0.756 \%, 0.085 \%, 0.082 \%$ and $0.005 \%$, respectively (Table 3 ). Our result is reliable with the result of Hassen (2016); Ibrahim et al. (2014); Ermiyas et al. (2015); Sisay et al. (2015). They revealed that the amount of input usage has a direct implication on grain production. But the coefficient of agrochemical input is negative (-0.0045) and statistically significant. This implies that, producers who used agrochemicals are less efficient compared to whom does not spray their farms. This can be explained by the facts that, as more of the large-scale grain crop producers can afford agrochemical input.

According to the field survey (2018/19), about 95\% of large-scale grain crop producers recognized for the fact that there is limited knowledge about the right proportions of inputs to apply; Hence, they may have over/under-applied, it leads to negative effects on yields, apply their sprays at the wrong time, using wrong ratios without scientific council and sometimes with inappropriate chemicals.

Table 3 Maximum Likelihood Estimation on the parameter of the Frontier Production Function

\begin{tabular}{|llll|}
\hline Variable & Parameter & Coefficient & Z-Value \\
\hline 1. Stochastic Frontier & & & \\
\hline Constant & $\beta_{0}$ & $8.0824^{* * *}$ & 22.17 \\
Lnseed & $\beta_{1}$ & $0.0045^{*}$ & 1.71 \\
Lnfertilizer & $\beta_{2}$ & 0.0016 & 1.47 \\
Lnlab & $\beta_{3}$ & $0.0892^{* * *}$ & 34.42 \\
L capital & $\beta_{4}$ & $0.0847^{* * *}$ & 5.47 \\
Lnlandsiz & $\mathrm{B}_{5}$ & $0.7461^{* * *}$ & 14.19 \\
Lnenergy & $\beta_{6}$ & 0.0004 & 1.29 \\
Lnagrochemical & $\beta_{7}$ & $-0.0045^{* * *}$ & -17.47 \\
\hline 2. Variance Parameter & & & \\
\hline Sigma_v & $\delta_{\mathrm{v}}$ & .0962 & \\
Sigma_u & $\delta_{\mathrm{u}}$ & .4767 & \\
Sigma-squared & $\sigma^{2}$ & 0.2365 & \\
Gamma & $\gamma$ & 0.96 & \\
Lambda & $\lambda$ & 4.96 & \\
Loglikelihood Function & & -28.92 & \\
Chibar2 (01) & & 26.16 & \\
Mean VIF & & 4.88 & \\
Mean TE & & 71.7 & \\
\hline
\end{tabular}

Source: Data Analysis, 2018/19. (***,**,* are 1, 5 and 10\% significant levels, respectively)

\subsection{Technical inefficiency determinants in the large-scale grain production (Inefficient model)}

The outcome in Table 4 shows that the coefficient of level of education has a negative sign and it indicates that there are increases in years of schooling reduce technical inefficiency; this relationship is significant at the one percent level. This is owing to the truth that education enhances productivity, 
skill, and technological adaptability for the farm practices in the study area. This result is in line with the finding of Alemu et al. (2009); Gatachew and Bamlaku (2014); Gemechu (2014); Hailemaraim (2015); Hassen (2016); Sisay et al. (2015); Solomon (2014).

The variable gender shows that, female, producers are found to be more competent than their counterpart. This is an analogous result with the finding of Addai and Owusu (2014); Alemu et al. (2009). This infers those female producers perform utmost of the agricultural doings in the study area, with recurrent follow-ups and administration than males.

On the contrary, the result shows that age, occupation, district, and subsidies variables have a positive sign, and therefore increase technical inefficiency. From the result the household head age showed a negative effect on the producers' technical efficiency, and it was significant at the $1 \%$ level. This revealed that, if there is an increase in the producers' age, the levels of technical efficiency decrease. This means that older producers were less technically efficient in grain production than their younger counterparts, consistent with findings by Kibara (2005); Amodu et al. (2011); Hailemaraim (2015); Haile et al. (2018). The finding accredited to the truth that older producers in the study area, are relatively more reluctant to take up better technologies. As a substitute, they want to grasp to the habitual agricultural scheme, hence become more technically inefficient compared to their younger equivalent.

The positive and significant coefficient of occupation variable indicates that producers engaged in offfarm income earning activities tend to exhibit higher levels of inefficiency. The positive relationship suggests that involvements in off-farm livelihood are escorted by reallocation of time left from the farm related activities. Such as, assembly of technical information and embracing of new technologies that is vital for enhancing production efficiency. It is concrete with the descriptive analysis, and findings by Alemu et al. (2009); Gemechu (2014);

Positive coefficient of the variable district is statistically significant at one percent. This indicated that, the large coefficient value shows the higher technical inefficiency. The result notifies that producer in the Metema district are less inefficient than producers in West Armachiho and Qura district, respectively. Probably, this could be explained by the sympathetic situation for grain production in the Metema district. On the other hand, the reason for the inefficiency of West Armachiho and Qura districts is, the less technical support they got from the responsible bodies; the lack of resources, to timely prepare their scenery apply inputs in time as they are far from the relating institutions and markets, lack of proper farm management. It is agreed with the result of Alemayehu (2010); Alemu et al. (2009); Hassen (2016).

The dummy variable subsidy coefficient indicates that there is a significant and positive influence on technical inefficiency. This indicates that subsidized producers are less efficient than the nonsubsidized producers. This result is in line with the arguments (Laure L and Yann D 2016). The result was totally different from the earlier expectation and to that of the descriptive analysis. However, it is tolerable, according to the revised FDRE, Investment Proclamation No.769/2005, article 1; the 
agricultural subsidy is given to only producers, who are owned above 200-hectare land. However, in the district about $59.5 \%$ of the respondents are owned below 200 hectares of land, so the proclamation neglects the large numbers of producers. Due to this, producers found to shift their area of production from such types of grain production to other sectors of the economy. This could ultimately let the producers to earn less than what they ought to produce.

Table 4. Technical inefficiency determinants in grain crop production (Inefficient mode)

\begin{tabular}{|lccc|}
\hline Variable & Parameter & Coefficient & Z-Value \\
\hline Constant & $\delta_{0}$ & $10.24 * * *$ & 18.29 \\
Age & $\delta_{1}$ & $0.0006 * * *$ & 17.48 \\
District & $\delta_{2}$ & $0.0544 * * *$ & 5.9 \\
Education & $\delta_{3}$ & $-0.0839^{* * *}$ & -3.05 \\
Extension contact & $\delta_{4}$ & -0.0647 & -1.19 \\
Gender & $\delta_{5}$ & $-0.0544 * * *$ & -10.25 \\
Occupation & $\delta_{6}$ & $0.0014^{* * *}$ & 17.34 \\
Subsidy & $\delta_{7}$ & $0.2052 * * *$ & 11.65 \\
Mean TE & & $71.7 \%$ & \\
\hline
\end{tabular}

Source: Data Analysis, 2018/19. (***,**,* are 1, 5 and 10\% significant levels, respectively)

The frequency distributions of efficiency estimate obtained from the stochastic frontier model presented in figure 2 , shows that, about $14 \%$ of the producers have an efficiency score less than $50 \%$. Many of the producers (about 66.5\%) have an efficiency score between 50 and $90 \%$. Only $19.5 \%$ of producers have an efficiency score greater than $90 \%$. The producer's technical efficiency ranging from a minimum of $23.3 \%$ and a maximum of $100 \%$ with $71.7 \%$ mean technical efficiency. This infers that on average, producers in the district incur about $28.3 \%$ loss in major grain output because of technical inefficiency.

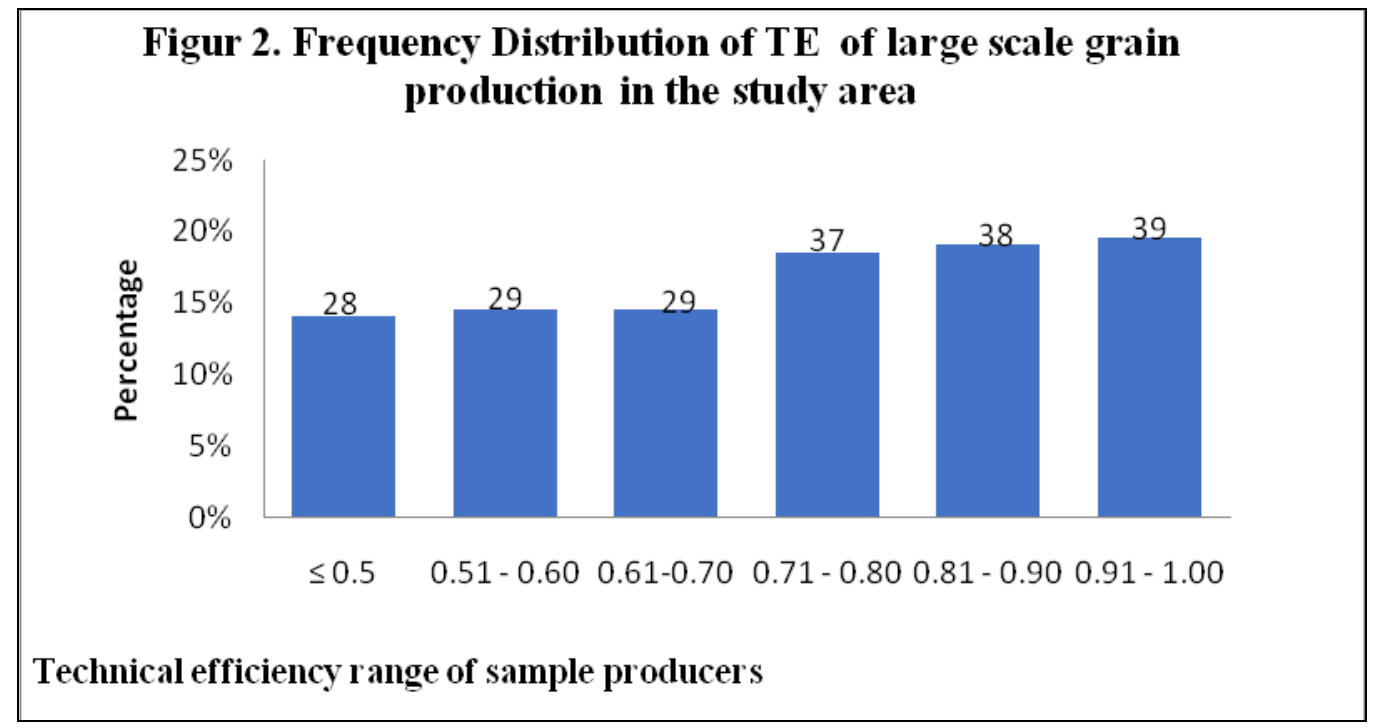

Figure 2. Source; Field survey, (2018/19)

The input elasticity and returns to scale results obtained from the stochastic frontier model presented in table 5 shows that. A one-percent increase in utilization of capital, labor and land inputs will increase the production by $0.18 \%, 0.23 \%$ and $0.56 \%$, respectively (Table 5 ). The study shows that the 
output has an uppermost compassion to land, followed by labor and capital inputs. As shown in the results from table 5, all the input elasticities are inelastic; indicating that a one percent increase in each input result in a less than one percent increase in yield (Alemu et al. 2009; Ibrahim et al. 2014; Ermiyas et al. 2015; Kibara 2005). The summation of the partial elasticity of production with respect to every input for a homogeneous function is 0.9592 . This represents the returns to- scale coefficient, also called the function coefficient or total output elasticity. If less than one, as shown in this result, a decreasing returns-to-scale exists. Therefore, an increase in all inputs by one percent increase grain crop yield by less than one percent.

Table 5. Input elasticity and returns to scale in the frontier production function

\begin{tabular}{|lll|}
\hline Variable input & Elasticity & P-value \\
\hline Labor input & .2300573 & 0.000 \\
Capital input & .1805164 & 0.000 \\
Land size & .5563797 & 0.000 \\
Agrochemical input & -.0068751 & 0.073 \\
RTS & 0.9592 & \\
\hline
\end{tabular}

Source: Field survey (2018/19).

\section{Conclusion and Recommendation}

Several empirical works have been conducted to investigate the smallholder farming level of technical efficiency. But technical efficiency level of the large-scale grain crop producers has not been studied much in Ethiopia. It should be noted that studies considering for large scale grain production will have important policy implication, to find proper development strategies and improve the current performance of the agriculture sector. Therefore, this study is conducted to check the level of technical efficiency and its determinants of the large-scale grain crop producers in Northwest of Ethiopia.

The result proved that the overall mean technical efficiency for the study area was $71.7 \%$. On the average, producers in the study district incur about 28.3 percent loss in grain output owing to technical inefficiency. Such variation in efficiency scores indicates producers' inefficiency in utilizing their resources, which further implies that, by fully utilizing the existing resources and technology, on the average grain production can be increased by at least $28 \%$.

The analysis of partial elasticity of grain production with respect to inputs reveals that yield is more responsive to land input use followed by labor and capital inputs. There is lower responsiveness of the yield to increase in seed, inorganic fertilizer, and agrochemical inputs.

Results from the estimation of the stochastic frontier model shows that the variable seed, labor, land size, and capital inputs are statistically significant and positively affect technical efficiency level of large-scale grain production. An increase the utilization of these inputs would increase production of the major grain crops. On the top of these, the maximum likelihood estimates of the stochastic frontier model proved that technical inefficiency of the producers significantly and negatively affected by the 
variable gender and levels of education. Whereas extension service, district, age and subsidy access were found to significantly and positively affect technical inefficiency of the producers.

The study recommends that education levels of the producers should be improved, and female producers ought to be given an opportunity in managing place on large scale grain farming sector. Government is obliged to offer strategies about proper input application and instigate the pilot research institution in the study areas since this would help reduce technical inefficiency. Therefore, the existing level of inefficiency in production of sesame, cotton and sorghum grain crop is high and this call for better attention of policy makers and researchers to improve technical efficiency of largescale grain crop producers.

\section{Abbreviations}

AfDB: African Development Bank; ARDS: Agricultural and Rural Development Sstrategy; CSA: Central Statistical Authority; EIAR: Ethiopian Institute of Agricultural Research; EIA: Ethiopian Investment Agency; EPLAUA: Environmental Protection Land Administration and Use Authority; FAO: Food and Agriculture Organization; FDRE: Federal Democratic Republic of Ethiopia; ha: hectare; MoARD: Ministry of Agriculture and Rural Development; MoFEC: Ministry of Finance and Economic Cooperation; MoFED: Ministry of Finance and Economic Development; MoTI: Minstry of trade and industry; NPC: National Planning Commission; SNNP: South nations, nationalities and people; UNDP: United Nations Environment Program; WFP: World Food Programme

\section{Acknowledgements}

I would like to express my sincere thanks to Dawit Melesse for reviewing the first draft of this paper. I enlarge my deep gratitude to Muluken Temesgen for his valuable comment. I also want to acknowledge the enumerators, respondents, and district experts for their appreciated response during the data collection process. The author also wishes to express his appreciation to the reviewers of the manuscript and the editors of JES for their in-depth comments, suggestions, and corrections, which have greatly improved the manuscript. Even though, the author is exclusively liable for any lingering fault.

\section{Authors' contributions}

The author instigated the research, wrote the research proposal, conducted the research, did data entry and analysis, and wrote the manuscript. And he also read and permitted the final manuscript.

\section{Funding}

Not applicable

\section{Availability of data and materials}

The author desires to announce that he can give the data sets used in this manuscript at any time based on the publishers inquire.

\section{Ethics approval and consent to participate}

Ethical approval and consent to partake is not pertinent for our study.

\section{Consent for publication}

Not applicable.

\section{Competing interests}

The author declares no competing interest about the publication of this manuscript

\section{Author details}

Author details: Department of Economics, College of Business and Economics, Bahir Dar University, P.O. BOX 79, Bahir Dar, Ethiopia. E-mail: woret2003@gmail.com

\section{References}

Abate B, Machel FV, Gezahegn A (2006) Effect of farm size on technical efficiency of teff production: a case study of the Moretina jiru district, central Ethiopia. Ethiopian Journal of Development Research 27 (1).

Abu T, Quintin G (2013) Ethiopia grain and feed annual report [Online] report number: ET-1301. available at: http://gain.fas.usda.gov/recent $\% 20$ gain $\% 20$ publications/grain $\% 20$ and $\% 20$ feed \% 20 annual Addis \%20Ababa_Ethiopia_4-17-2012.pdf [Accessed 09 December 2013] 
Addai KN, Owusu V (2014). Technical efficiency of maize farmers across various agro ecological zones of Ghana. Journal of Agriculture \& Environmental Sciences 3(1): 149-72

African Development Bank (AfDB) (2016) Federal democratic republic of Ethiopia: country strategy paper-CSP, 2016-20

Ahmed M, Melesse K (2018) Impact of off-farm activities on technical efficiency: evidence from maize producers of eastern Ethiopia. Agricultural and Food Economics 6(3). https://doi.org/10.1186/s40100-018-0098-0

Alemayehu E (2010) Analysis of factors affecting the technical efficiency of coffee producers in Jimma Zone. A Stochastic Frontier Analysis. MSc Thesis, Addis Ababa University, Addis Ababa, Ethiopia

Alemu BA, Nuppenau EA, Boland H (2009) Technical efficiency of farming systems across agro ecological zones in Ethiopia: an application of stochastic frontier analysis. Agricultural Journal 4(4): 202-207

Aligner DJ, Lovell CA, Schmidt PJ (1977) Formulation and estimation of stochastic frontier production models. Journal of Econometrics 6

Amhara Regional State Environmental Protection Land Administration and Use Authority (EPLAUA) (2017/18) Proclamation No 769/2005, rural land administration and land use proclamation Bahir Dar, Ethiopia

Amodu MY, Owolabi JO, Adeola SS (2011) Resource use efficiency in part-time food crop production: the stochastic frontier approach. Nigerian J Basic ApplSci 19 (1): 102

Battese G.E, Coelli T (1995) A model of technical efficiency effects in a stochastic frontier production function for panel data. Empirical Economics 20 (2): 325-332

Central Statistical Authority (CSA) (2014) Agricultural sample survey AgSS 2013-2014, report on area and production of major crops, volume I, Addis Ababa, Ethiopia

Central Statistics Authority (CSA) (2016) Agricultural sample survey 2015/2016, report on area and production of major crops, volume I, CSA, Addis Ababa, Ethiopia

Central Statistical Authority (CSA) (2018) Agricultural sample survey 2017/18, report on area and production for major crops, volume I, Addis Ababa, Ethiopia.

Central Statistical Authority (CSA) (2019) Agricultural sample surveys 2018/19, report on area and production of major crops, volume I, Addis Ababa, Ethiopia

Chakwera SJ (2015) A survey on technical, allocative, and economic efficiency of maize production using the parametric stochastic frontier production function. African Journal of Agricultural Economics and Rural Development 3 (6): 237-245

Coelli T (1995) Recent developments in frontier modelling and efficiency measurements. Australian Journal of Agricultural Economics 39: 219-245

Ethiopian Investment Agency (EIA) (2012/13) Cotton production and ginning in Ethiopia

Ethiopian Institute of Agricultural Research (EIAR) (2011) Website: http://www.eiar.gov.et

Ermiyas M, Endrias G, Belaineh L (2015) Production efficiency of sesame in Selamago district of South Omo Zone, Southern Ethiopia. Current Research in Agricultural Sciences 2(1): 8-21.

FAOSTAT (2016) Crop production in Africa. Retrieved 2018, August 18. Countries-select all; regions-Africa + (Total); elements—area and production quantity; items—red pepper; Years2010-2016. http://www.fao.org/faost at/en/\#data/ QC/ [Online]

Federal Democratic Republic of Ethiopia (FDRE) (2016) Agricultural sample surveys 2015/16, report on area and production of major crops, volume I, III, Addis Ababa, Ethiopia

Food and Agricultural Organization (FAO), World Food Programme (WFP) (2012) Crop and food security assessment mission to Ethiopia. Special Report of Food and Agriculture Organization and World Food Programme

Food and Agricultural Organization (FAO), World Food Programme (WFP) (2018) Crop and food security assessment mission to Ethiopia. Special Report of Food and Agriculture Organization and World Food Programme

Gelalcha SD (2009) Sesame trade arrangements, costs, and risks in Ethiopia. Ministry of Foreign Affairs, The Hague.

Getachew M, Bamlak A (2014) Analysis of technical efficiency of small holder maize growing farmers of Horo Guduru Wollega zone, Ethiopia: a stochastic frontier approach. Sci Technol Arts Res J 3(3):204-212 
Getahun G (2014) Off-farm income and technical efficiency of small-scale farmers in Ethiopia: a stochastic frontier analysis. MSc Thesis, Swedish University of Agricultural Sciences (SLU), Uppsala, Sweden.

Haile K, Haji J, Tegegne B (2018) Technical efficiency of sorghum production: the case of smallholder farmers in Konso district, Southern Ethiopia. AgricDev 3:1-15

Hailemaraim L (2015) Technical efficiency in teff production: the case of Bereh district, Oromia National, Regional State, Ethiopia (Doctoral dissertation, Haramaya University)

Hassen B (2016) Technical efficiency measurement and their differential in wheat production: the case of smallholder farmers in South Wollo. Int J Econ Bus Finance 4 (1): 1-16

Ibrahim UW, Umar A.S.S, Ahmed B (2014) Technical efficiency and its determinants in watermelon production in Borno State, Nigeria. Journal of Economics and Sustainable Development, 5 (27): 205-2011

Kibara B (2005) Technical efficiency of Kenya's maize production: an application of stochastic frontier approach. MSc Thesis, Colorado State University, USA

Kifle D, Moti J, Belaineh L (2017) Economic efficiency of smallholder farmers in maize production in BakoTibe district, Ethiopia. J DevCtry Stud 7(2):80-86

Kumbhakar S. C, Lovell C. A. K (2000) Stochastic frontier analysis. Cambridge University press, Cambridge, United Kingdom

Laure L, Yann D (2016) Common agricultural policy support, technical efficiency and productivity change in French agriculture. Rev Agric Food Environ Stud 97:15-28

Meeusen W, Van den Broeck J (1977) Efficiency estimation from a Cobb-Douglas production functions with composed error. International Economic Review, 18:435-444.

Ministry of Agriculture and Rural Development (MoARD) (2010) Ethiopia's agricultural and sector policy and investment framework (ASPIF): 2010-2020, Addis Ababa, Ethiopia

Ministry of Finance and Economic Cooperation (MoFEC) (2015) Development and poverty profile of Ethiopia. Addis Ababa, Ethiopia

Musa HA, Lemma Z, Endrias G (2014) Technical efficiency of maize producing farmers in Arsi Negelle, central rift valley of Ethiopia: stochastic frontier approach. J Agric for 60(1):157-167

National Planning Commission (NPC) (2016) Growth and Transformation Plan (GTP) II 2015/162019/20. The Federal Democratic Republic of Ethiopia, volume, 1. Addis Ababa, Ethiopia

Sisay D, Haji J, Goshu D, Edriss AK (2015) Technical, allocative, and economic efficiency among smallholder maize farmers in Southwestern Ethiopia. Journal of Development and Agricultural Economics 7: 283-292

Solomon B (2014) Technical efficiency of major crops in Ethiopia: stochastic frontier model: master thesis for the Master of Philosophy in environmental and development economics, Universities I OSLO

Tchale H, Sauer J (2007) The efficiency of maize farming in Malawi: a bootstrapped translog frontier', Cahiers d'economieet sociologierurales 1: 82-83

United Nations Environment Program (UNDP) (2015) Country climate change framework. environment and disaster risk management portfolio: Ethiopia

United States Department of Agriculture (USDA) (2018) Foreign agriculture service global agricultural information network report on Ethiopian cotton production. Addis Ababa, Ethiopia

Wijnands HM, Biersteker J, Heil R (2007) Oilseed's business opportunities in Ethiopia. The Hague

World Bank (2017) World Bank in Ethiopia: Country's Economic Overview. Washington, DC: The World Bank

World Food Program (WFP) (2010) Summary of food security and vulnerability in selected cities of Ethiopia. Addis Ababa, Ethiopia 